\title{
Food Values, Satisfaction, and Loyalty: Some Evidence in Grocery Retailing Acquired during the COVID-19 Pandemic
}

\author{
Ana Isabel Muro-Rodríguez ${ }^{1, *}$, Israel Roberto Pérez-Jiménez ${ }^{1}$, Andrea Esteban-Dorado ${ }^{1}$ \\ and María Pilar Martínez-Ruiz ${ }^{2}$ (D) \\ 1 Department of Spanish and International Economic, Econometrics and Economic History, University of \\ Castilla-La Mancha, 45071 Toledo, Spain; IRoberto.Perez@uclm.es (I.R.P.-J.); \\ Andrea.Esteban@alu.uclm.es (A.E.-D.) \\ 2 School of Economics and Business Sciences, University of Castilla-La Mancha, 02071 Albacete, Spain; \\ MariaPilar.Martinez@uclm.es \\ * Correspondence: AnaIsabel.Muro@uclm.es
}

check for updates

Citation: Muro-Rodríguez, A.I.; Pérez-Jiménez, I.R.; Esteban-Dorado, A.; Martínez-Ruiz, M.P. Food Values, Satisfaction, and Loyalty: Some Evidence in Grocery Retailing Acquired during the COVID-19 Pandemic. Sustainability 2021, 13, 3908. https://doi.org/10.3390/ su13073908

Academic Editor: Michael Carolan

Received: 9 March 2021

Accepted: 28 March 2021

Published: 1 April 2021

Publisher's Note: MDPI stays neutral with regard to jurisdictional claims in published maps and institutional affiliations.

Copyright: (c) 2021 by the authors. Licensee MDPI, Basel, Switzerland. This article is an open access article distributed under the terms and conditions of the Creative Commons Attribution (CC BY) license (https:/ / creativecommons.org/licenses/by/ $4.0 /)$.

\begin{abstract}
Recent evidence illuminates the importance of relatively new concepts in grocery retailing, such as the concept of food values. The present work aims at analyzing the influence of: (i) food values on key non-financial results, particularly satisfaction and loyalty; and (ii) satisfaction on loyalty. The paper makes a further delineation for both satisfaction and loyalty (i.e., with the product and with the grocery store), as well as considers the potential implications derived from the COVID-19 pandemic. With these objectives in mind, the paper distributed an online survey to the residents of Toledo (Spain) during April and May 2020 (a period characterized by a national lockdown, where grocery stores and essential business were open to the public). This effort produced 303 valid questionnaires and the resulting data were analyzed by using descriptive statistics alongside linear parametric regressions. The findings show how food values have a positive and significant influence on both types of satisfaction and loyalty; there is also a significant and positive influence of both types of satisfaction on both types of loyalty. Moreover, the results corroborate previous works about the most influential food values. These findings highlight the importance of considering food values in grocery retailing in order to achieve key non-financial benefits. The paper ends with a discussion of several interesting managerial guidelines, particularly in light of situations like the COVID-19 pandemic.
\end{abstract}

Keywords: grocery retailing; grocery store; food; consumer satisfaction; consumer loyalty

\section{Introduction}

Traditionally, scholars have thought that consumers normally buy food on the basis of the attributes that they want the food products to have [1]. Unsurprisingly, then, the first publications on food buying decisions primarily studied the attributes of food products, especially those that could be quantified and measured [2].

Within this research field, Lusk and Briggeman (2006) [3] were among the first to propose a food values scale: another perspective on food that is key to understanding how people develop preferences for certain foods over others. This notion has direct implications for operators in the food industry, who want to understand what customers think about their products and services, which may ultimately affect non-financial results such as consumer satisfaction and loyalty [4]. There is also an important relationship between consumer satisfaction and consumer loyalty: usually, a consumer who is satisfied (with a certain product, grocery store, etc.) will: (i) repeat the purchase (of the same product, in the same grocery store, etc.), which relates to behavioral loyalty; and (ii) recommend the product and/or store to other consumers, which relates to attitudinal loyalty [5].

Although some previous works have analyzed the influence of food values on satisfaction and loyalty (e.g., Izquierdo-Yusta et al., 2019; Izquierdo-Yusta et al., 2020 [6,7]), 
there is a need to analyze the influence of food values on satisfaction and loyalty in a more nuanced way. In other words, we need to assess the influence of: (i) food values on satisfaction and loyalty, both with the product and with the grocery store; and (ii) the influence of both types of satisfaction (with the product and with the grocery store) on both types of loyalty (with the product and with the grocery store). This line of research becomes especially relevant when considering the recent market changes brought on by the COVID-19 pandemic. Trying to know whether consumers will attach more importance to either product-related or grocery store-related aspects after the changes brought about by the Covid-19 pandemic, will be an essential aspect for food industry operators.

Therefore, the objective of this research is to analyze: (i) whether food values influence both satisfaction and loyalty (both with the product and the grocery store); (ii) whether a consumer's satisfaction with a certain product or grocery store may lead to loyalty (to the product and/or to the grocery store). The data for this study were collected in the midst of the COVID-19 pandemic, which entailed changes in the reference environment (a national lockdown where only food stores and essential businesses were open to the public) that may have potentially modified consumers' habits in interesting ways.

The remainder of this paper is as follows: in the next section, we present the conceptual framework of this research. In the third section, we describe the methodology and results of this research. Finally, the fourth section describes our main conclusions.

\section{Conceptual Framework}

In this section, we define the key variables of this research: food values, satisfaction, and loyalty. We end the section by presenting the conceptual framework, which will allow us to formulate a series of hypotheses about these key relationships.

\subsection{Food Values}

Departing from the work of Rokeach (1973) [8] on consumer values, Schwartz (1992) [9] extended this research and identified 56 universal values and classified them into ten groups, such as tradition, security, or hedonism, among others. Steptoe, Pollard, and Wardle (1995) [10], departing from the previous universal values, described the importance of exploring how different values influence food choice; to this end, they developed the Food Choice Questionnaire (FCQ) to measure the food choice motivations. According to their findings, the most important factors for food choice were convenience, price, mood, sensory appeal, weight control, ethical concern, health, natural content, and familiarity.

Working with these antecedents, Lusk and Briggeman (2006) [3] published the first food values scale, which featured 11 values. This scale represented a milestone in not only the field of agricultural economics, but also in related fields such as marketing, as it began to identify other relevant aspects of food. For example, this values scale is closely connected with one of the later marketing approaches, Marketing 3.0, whereby marketing treats individuals not merely as consumers, but as human beings with minds, hearts, and spirits. This is why Marketing 3.0 is also known as the values-driven era, since consumers' personal values are incorporated into marketing decisions (Martínez-Ruiz and Gómez-Cantó, 2016) [2].

Lusk and Briggeman (2006) [3] specifically examined how preferences explain food choices. However, preferences are not stable over time; therefore, it is important to investigate individuals' values, which are generally more stable than preferences. Like Steptoe, Pollard, and Wardle [10] used the universal values of Schwartz [9] as a starting point for their research. However, Lusk and Briggeman (2006) [3] concluded that certain groups of values were not directly related to food, and thus, it was necessary to create food-specific values. Several researchers have conducted research to create food values, but according to Lusk and Briggeman ([3], p. 186), the results were "too specific to be applied widely in explaining consumers' food choices in a variety of foods." Contrary to previous research, Lusk and Briggeman's [3] aim was to create values that were stable over time and applicable to a wide range of food products. Instead of a questionnaire, Lusk and Briggeman [3] used 
the best-worst scale to measure the sequences of the different values-although they "have no illusions that other researchers could have generated a slightly different list" [3] p. 187. The food values proposed were: naturalness (degree to which food is produced without modern technologies); taste (degree to which food consumption is attractive to the senses); price (the price paid for food); safety (the degree to which the consumption of food will not cause illness); convenience (ease with which food is cooked and/or consumed); quantity (nutritional and type of fats, proteins, vitamins, etc.); tradition (preservation of traditional consumption patterns); origin (where the agricultural products were grown); equity (the extent to which all parties involved in food production benefit equally); appearance (degree to which the food looks attractive); and environmental impact (effect of food production on the environment).

Bazzani et al. [11] then used the above list of food values to compare the most appreciated values in Norway and the United States, albeit while making some distinct changes. In particular, these authors added two new values-novelty and animal welfare-while removing the value of tradition. They decided to add the value of novelty in light of the fact that, owing to improved food technologies and the growth of globalization, companies are continually offering new products to their customers. In addition, they demonstrated that the search for new products is a key component of people's purchasing decisions. They also added the value of animal welfare in response to the increasing societal concern for animal welfare - that is, the degree to which animal rights are respected throughout the life process, from birth to death. Finally, they decided to eliminate the value of tradition because it might seem counterintuitive next to questions about the growth of globalization and new ways of making products. Moreover, because each country has a different concept of tradition, the authors thought the question might confuse respondents.

While these values may seem very similar to certain attributes of food products, they represent more abstract concepts that simultaneously involve numerous physical attributes. Ultimately, these values provide consumers with a framework for evaluating various food alternatives in accordance with their own wishes and needs. This is important in light of societal changes, where today's consumers care about what they eat and value things that were not considered in the past. Novelli [12] revealed that today's consumers still treat price, safety, and taste as their main issues, but other values such as origin, fairness, environmental impact, or naturalness are receiving growing attention.

In general, our literature review indicates that food values greatly influence satisfaction and loyalty, although the influence changes depending on the type of endogenous variable considered (satisfaction and loyalty with the products purchased, or with the grocery store) (c.f., Izquierdo-Yusta et al., 2020) [7]. Following from this, we propose the following research hypotheses:

Hypothesis 1 (H1). Food values positively and significantly influence satisfaction.

Hypothesis 1 (H1a). Food values positively and significantly influence satisfaction with the product.

Hypothesis 1 (H1b). Food values positively and significantly influence satisfaction with the grocery store.

Hypothesis 2 (H2). Food values positively and significantly influence loyalty.

Hypothesis 2 (H2a). Food values positively and significantly influence loyalty with the product.

Hypothesis 2 (H2b). Food values positively and significantly influence loyalty with the grocery store.

\subsection{Satisfaction and Loyalty}

Izquierdo-Yusta et al. (2020) [7] highlighted that consumer satisfaction is generally a global evaluation (or a state of feelings) toward a product (tangible and intangible) or 
a store (Olsen et al., 2005) [13]. Satisfaction is usually conceptualized as the outcome of the subjective evaluation that the chosen alternative meets or exceeds expectations (Bloemer and Ruyter, 1998) [14]. Satisfaction with products or stores arises from comparing expectations with perceptions: (1) If the perception does not match the expectation, the customer will be dissatisfied; (2) if the perception matches the expectation, the customer will be satisfied; (3) if the perception exceeds the expectation, the customer will be more than satisfied (Sudari et al.) [15]. In short, satisfaction arises when consumers' perceptions are equal to, or in excess of, their expectations.

Consumer satisfaction is usually considered a response (emotional or cognitive) with a particular focus (e.g., product experience; consumption experience) that occurs at a particular time (e.g., after choice; after consumption), for a particular duration, at varying intensity (Giese and Cote, 2000) [16]. When talking about satisfaction from food products, it is worth highlighting the particular food properties that can contribute to this kind of satisfaction. While there are diverse aspects that likely impact food satisfaction, consumers express the most appreciation for the hedonic and/or sensory aspects, although the relevance of each aspect differs for each person (Izquierdo-Yusta et al., 2020) [6]. For example, research has observed that the origin or provenance of food (Stefani et al., 2006) [17], as well as the texture, appearance and taste (Vad Andersend and Hyldig (2015) [18], all influence satisfaction.

Satisfied customers are more impressed by a retailer's products and services, which plays an important role in future purchases. In this sense, satisfaction can vary based not only on the values offered by the food, but also on the values offered by the grocery store itself. Of course, consumers maintain highly heterogeneous expectations (Huddleston et al., 2009; Izquierdo-Yusta et al., 2020) [7,19], which has motivated diverse research into consumer satisfaction with food purchases based on the retail format (Carpenter et al., 2005; Carpenter and Moore, 2006; Izquierdo-Yusta et al., 2020) [7,20,21]. Understanding these differences may help retailers implement retail formats and offer products that differentiate them from their competitors.

It is also important to study loyalty in the context of food retailing, since this variable is integral to consumers' post-purchase processes (Izquierdo-Yusta et al., 2020) [7]. Indeed, retailers reap several benefits from creating and maintaining a loyal customer base: For instance, loyal customers are more frequently profitable, since they are not sensitive to price variations and are willing to devote a greater share of their budget to buying a certain brand or shopping at their preferred grocery store. In addition, loyal customers are less likely to search for competing brands or switch stores, since the switching costs could be higher (East et al., 1995) [22].

In the context of grocery retailing, the concept of loyalty overlaps with the notion of relational commitment, which the relationship marketing literature usually describes as an enduring desire to stay in a valuable relationship (Anderson and Weitz, 1992; Moorman et al., 1992; Morgan and Hunt, 1994) [23-25]. More specifically, loyalty reflects the buyer's overall attachment, or deep commitment, to a product, service, brand, or organization (Oliver, 1999) [26]. On this point, we want to emphasize that people can express loyalty toward the product, the grocery store, or both.

\subsection{The Influence of Satisfaction on Loyalty}

As pointed out by Izquierdo-Yusta et al. (2020) [7], satisfied customers are generally less motivated to seek and evaluate other buying alternatives (Liu, 2006) [27]. For this reason, satisfaction is usually regarded as a necessary step in the loyalty-building process, although it may become less significant when other mechanisms (e.g., social or personal ties) come into play (Oliver, 1999) [26]. Indeed, scholars generally acknowledge that consumer satisfaction and loyalty are interconnected variables (Meesala \& Paul) [28], with improvements to the former leading to improvements in the latter. For example, Hu et al. [29] observed that higher customer satisfaction increased customer loyalty and decreased customer complaints. Dudek-Burlikowska and Szewieczek [30] suggested that 
customers' complaints were an indicator of low customer satisfaction (granted, their absence does not imply high customer satisfaction). Furthermore, several marketing studies suggest that the satisfaction of customers' needs constitute one of the antecedents of loyalty, regardless of whether the context is a brand or a particular store (Deng et al., 2010; Fornell et al., 1996; Gustafsson et al., 2005; Mittal \& Kamakura, 2001; Bloemer \& Ruyter, 1998) [14,31-34].

However, while customer satisfaction has long been considered a clear antecedent of loyalty, some authors (e.g., Mittal \& Lassar, 1998) [35] have shown that a satisfied customer is not always a loyal one. These authors based their arguments on two possible pathways: A dissatisfied customer could continue to buy the same brand or go to the same store if he/she cannot find anything better among the available alternatives; and a satisfied customer may be willing to purchase new brands or go to a new provider in the hopes of achieving more favorable results (Izquierdo-Yusta et al., 2020) [7]. Thus, it seems that the relationship between customer satisfaction and loyalty, while generally positive, may be subject to moderators and contextual factors.

In light of these ideas, we formulated the following hypotheses:

Hypothesis 3 (H3). Satisfaction positively and significantly influences loyalty.

Hypothesis 3 (H3a). Satisfaction with the product positively and significantly influences loyalty toward the product.

Hypothesis $3 \mathbf{~ ( H 3 b ) . ~ S a t i s f a c t i o n ~ w i t h ~ t h e ~ g r o c e r y ~ s t o r e ~ p o s i t i v e l y ~ a n d ~ s i g n i f i c a n t l y ~ i n f l u e n c e s ~}$ loyalty toward the grocery store.

Hypothesis 3 (H3c). Satisfaction with the product positively and significantly influences loyalty toward the grocery store.

Hypothesis 3 (H3d). Satisfaction with the grocery store positively and significantly influences loyalty toward the product.

\section{Materials and Methods}

\subsection{Methodology}

We adopted an online questionnaire in order to collect the data. In order to reach the largest number of respondents, we distributed the questionnaire through the most prominent social networks: WhatsApp, Facebook, and Instagram.

The questionnaire sought to obtain information about respondents' last food purchase in a physical grocery store. Specifically, we gathered information about the study variables (food values, satisfaction, and loyalty) and the participants' socio-demographic profile.

The first two questions respectively focused on the type of commercial grocery store where the last purchase was made, and the frequency of that particular purchase.

The following questions dealt with the food values scales, which were adapted from the 11 items developed by Lusk and Briggeman [3], while incorporating the two variables introduced by Bazzani et al. [11] (novelty and animal welfare). These questions asked respondents to indicate their appreciation for the corresponding value on a scale from 1 (least appreciated) to 5 (most appreciated).

The third group of questions gathered information about satisfaction and loyalty, with both the product and the grocery store. Using Likert scales with five possible answers, respondents indicated their degree of agreement or disagreement with each statement. The scales were inspired by Kamram-Disfani et al. (2017) [36] and Izquierdo-Yusta et al. (2020) [7].

Finally, the questionnaire ended with socioeconomic questions (gender, structure of the household, monthly household income, age, and level of studies).

Table 1 shows a description of the questions and variables employed in the questionnaire. 
Table 1. Description of variables.

\begin{tabular}{|c|c|}
\hline Variable & Scale Description \\
\hline Type of grocery store & $\begin{array}{l}\text { Hypermarket } \\
\text { Supermarket } \\
\text { Discount store } \\
\text { Convenience store } \\
\text { Supply market } \\
\text { Others }\end{array}$ \\
\hline Frequency of purchase & $\begin{array}{c}\text { Once a day } \\
\text { 2/3 times a week } \\
\text { Once a week } \\
\text { Once a fortnight } \\
\text { Once a month }\end{array}$ \\
\hline $\begin{array}{l}\text { Food values scale } 1-5 \\
(1=\text { not at all appreciated to } 5=\text { very } \\
\text { much appreciated })\end{array}$ & $\begin{array}{c}\text { V8FV: Origin } \\
\text { V9FV: Fairness } \\
\text { V10FV: Appearance } \\
\text { V11FV: Environmental impact } \\
\text { V12FV: Novelty } \\
\text { V13FV: Animal welfare }\end{array}$ \\
\hline $\begin{array}{c}\text { Satisfaction with the product. } \\
\text { Satisfaction scale } 1-5 \\
\text { (1 }=\text { the smallest degree of agreement to } \\
5=\text { the greatest degree of agreement }]\end{array}$ & $\begin{array}{l}\text { V1SP: Degree of satisfaction with the food you purchased in that last purchase } \\
\text { V2SP: The food I bought met my expectations } \\
\text { V3SP: The choice of these foods seemed right to me } \\
\text { V4SP: The food I bought provided me with an enjoyable experience }\end{array}$ \\
\hline
\end{tabular}

Satisfaction with the grocery store

( $1=$ the smallest degree of agreement to

$5=$ the greatest degree of agreement)

V1SE: I was satisfied with the in-store shopping experience

Loyalty with the product Agreement scale 1-5

( $1=$ the smallest degree of agreement to $5=$ the greatest]

Loyalty with the grocery store Agreement scale 1-5

( $1=$ the smallest degree of agreement to

$5=$ the greatest degree of agreement]
V1LP: Most of the time I shop, I buy the same foods V2LP: Whenever I can, I recommend these foods V3LP: I intend to keep buying these foods

\begin{tabular}{|c|c|c|}
\hline Gender & \multicolumn{2}{|c|}{$\begin{array}{c}\text { Man } \\
\text { Woman }\end{array}$} \\
\hline Structure of the household & \multicolumn{2}{|c|}{$\begin{array}{c}\text { Single/separate/widowed without children } \\
\text { Single/separate/widowed with children } \\
\text { Couple without children } \\
\text { Couple with children up to } 6 \text { years old } \\
\text { Couple with children over } 6 \text { and up to } 12 \text { years old } \\
\text { Couple with children over } 12 \text { years old }\end{array}$} \\
\hline Monthly household income & $\begin{array}{c}\text { Up to } 900 € \\
901 € \text { to } 1200 € \\
1201 € \text { to } 1800 €\end{array}$ & $\begin{array}{c}1801 € \text { to } 2100 € \\
2101 € \text { to } 2800 € \\
\text { More than } 2800 €\end{array}$ \\
\hline Age & $\begin{array}{c}\text { Up to } 25 \text { years } \\
\text { From } 26 \text { to } 45 \text { years old }\end{array}$ & $\begin{array}{l}\text { From } 46 \text { to } 65 \text { years old } \\
\text { Over } 65 \text { years old }\end{array}$ \\
\hline Educational level & $\begin{array}{c}\text { Basic } \\
\text { Secondary }\end{array}$ & $\begin{array}{c}\text { University } \\
\text { Master/Doctorate }\end{array}$ \\
\hline
\end{tabular}

The sample exclusively comprised individuals who lived in the province of Toledo (Spain). The data collection took place from 15 April 2020 to 4 May 2020. During this period, the country was under lockdown due to the COVID-19 health crisis, and consequently, all information was collected online. Specifically, the questionnaire was administered 
through social networks to reach the largest number of people. The social networks used were WhatsApp, Facebook, and Instagram, as they were considered the most used social networks by the target population.

In the end, we obtained a total of 303 complete responses. Table 2 shows the technical details of the questionnaire.

Table 2. Technical details of the questionnaire.

\begin{tabular}{cc}
\hline Universe & $\begin{array}{c}\text { Resident Population in the Province of } \\
\text { Toledo (695,013 People [37]) }\end{array}$ \\
\hline Sample unit & Residents in the province of Toledo \\
\hline Data collection method & Online surveys sent through social networks \\
\hline Number surveyed & 303 valid surveys \\
\hline Period of information collection & 15 April-4 May (2020) \\
\hline
\end{tabular}

\subsection{Empirical Analysis}

We applied a frequency analysis, shown in Table 3, to assess the profile of the study respondents. The analysis indicated that most of the respondents were women; the predominant age group was 25 to 46 , with respondents under 46 representing $83.8 \%$ of the entire survey. With regard to the household structure, the sample was largely balanced between people living alone (with or without children) and people living as a couple (with or without children). The respondents were also more or less equal in terms of their educational attainment, with the bulk of people holding university degrees, and a smaller number holding masters or doctorate degrees.

Table 3. Descriptive statistics of respondents' characteristics.

\begin{tabular}{|c|c|c|c|c|c|}
\hline Description & Variable & $\begin{array}{l}\text { Frequency } \\
\text { Distribution }\end{array}$ & Description & Variable & $\begin{array}{c}\text { Frequency } \\
\text { Distribution }\end{array}$ \\
\hline \multirow{6}{*}{$\begin{array}{c}\text { Type of grocery store } \\
\text { Where last purchase } \\
\text { was made }\end{array}$} & Hypermarket & 45 & \multirow{6}{*}{$\begin{array}{l}\text { Frequency of } \\
\text { purchase }\end{array}$} & Once a day & 8 \\
\hline & Supermarket & 201 & & $2 / 3$ times a week & 66 \\
\hline & Discount store & 32 & & Once a week & 179 \\
\hline & Convenience store & 1 & & Once a fortnight & 40 \\
\hline & Supply market & 11 & & Once a month & 10 \\
\hline & Others & 13 & & & \\
\hline \multirow{4}{*}{ Gender } & \multirow{3}{*}{ Man } & \multirow{2}{*}{96} & \multirow{4}{*}{$\begin{array}{l}\text { Level of } \\
\text { completed } \\
\text { studies }\end{array}$} & Basic & 47 \\
\hline & & & & Secondary & 92 \\
\hline & & \multirow{2}{*}{207} & & University & 130 \\
\hline & Woman & & & Master/Doctorate & 34 \\
\hline \multirow{6}{*}{$\begin{array}{l}\text { Monthly household } \\
\text { income }\end{array}$} & Up to $900 €$ & 61 & \multirow{6}{*}{ Age } & Up to 25 years & 123 \\
\hline & $901 €$ to $1200 €$ & 52 & & From 26 to 45 years & 131 \\
\hline & $1201 €$ to $1800 €$ & 86 & & From 46 to 65 years & 43 \\
\hline & $1801 €$ to $2100 €$ & 42 & & Over 65 years old & 6 \\
\hline & $2101 €$ to $2800 €$ & 32 & & & \\
\hline & More than $2800 €$ & 30 & & & \\
\hline \multirow{3}{*}{$\begin{array}{l}\text { Structure of the } \\
\text { household }\end{array}$} & $\begin{array}{l}\text { Single/separate/widowed } \\
\text { without children }\end{array}$ & 127 & \multirow{3}{*}{$\begin{array}{l}\text { Structure of the } \\
\text { household }\end{array}$} & $\begin{array}{l}\text { Couple with children } \\
\text { up to } 6 \text { years old }\end{array}$ & 23 \\
\hline & $\begin{array}{l}\text { Single/separate/widowed } \\
\text { with children }\end{array}$ & 12 & & $\begin{array}{l}\text { Couple with children } \\
\text { over } 6 \text { and up to } \\
12 \text { years old }\end{array}$ & 9 \\
\hline & Couple without children & 65 & & $\begin{array}{l}\text { Couple with children } \\
\text { over } 12 \text { years old }\end{array}$ & 67 \\
\hline
\end{tabular}

Regarding the type of grocery store where the last purchase was made, the majority of respondents listed supermarkets. Regarding the purchase frequency, most of the respon- 
dents usually buy once, twice, or even three times a week. Regarding monthly household income, respondents were fairly equally distributed, with the largest segment belonging to the 1201-1800 euro salary range.

Table 4 shows the descriptive statistics for the food values variables. The most appreciated values, in this order, were taste (4.48), safety (4.16), and naturalness (3.91). However, the respondents signaled less appreciation for novelty (2.82), fairness (2.94), and origin (3.00). These findings align with those of Izquierdo-Yusta et al. (This study only considered the food values of Lusk and Briggeman (2009) while excluding the values of novelty and animal welfare of Bazzani et al. (2018). The data were gathered in 2017 in another Spanish city, Albacete, that belongs to the same region, Castilla-La Mancha, where we gathered our data.) [7], who found that taste and safety were the most appreciated values, while fairness and origin were the least appreciated. All the food values attained a median of 3 or higher, with a value of 5 being attained for the taste and safety values. It is also possible to establish that the most repeated value for all the food values is above 3 , with many of them attaining a value of 5, as shown by the mode. Finally, the data show that the food value with the most shared opinion was taste (0.825), while the value with the highest dispersion among respondents was origin (1.278).

Table 4. Descriptive statistics of food values.

\begin{tabular}{ccccc}
\hline Variable & Mean & Median & Mode & Standard Deviation \\
\hline Naturalness & 3.91 & 4 & 5 & 1.164 \\
Taste & 4.48 & 5 & 5 & 0.825 \\
Price & 3.85 & 4 & 5 & 1.097 \\
Safety & 4.16 & 5 & 5 & 1.138 \\
Convenience & 3.45 & 3 & 3 & 1.152 \\
Nutrition & 3.64 & 4 & 5 & 1.234 \\
Tradition & 3.41 & 3 & 3 & 1.17 \\
Origin & 3 & 3 & 3 & 1.278 \\
Fairness & 2.94 & 3 & 3 & 1.263 \\
Appearance & 3.67 & 4 & 4 & 1.106 \\
Environmental impact & 3.06 & 3 & 3 & 1.182 \\
Novelty & 2.82 & 3 & 3 & 1.265 \\
Animal welfare & 3.05 & 3 & 3 & \\
\hline
\end{tabular}

The analysis in Table 5 shows the descriptive statistics for the satisfaction and loyalty variables. Regarding respondents' satisfaction, the variable "The choice of these foods seemed right to me" attained a slightly higher mean than the rest (4.18) and one of the lowest standard deviations (0.817). Thus, we can infer that most respondents largely felt right about their food purchase. Regarding respondents' loyalty, the variable "I intend to keep coming to this grocery store" achieved the highest mean value (4.37) and the lowest standard deviation (0.778). The variable "Whenever I can, I recommend these foods" is also notable: It attained the lowest mean (3.45) and the highest standard deviation (1.189), signifying that the respondents gave very different answers to this question.

In order to establish an association between the food values and the post-purchase variables of satisfaction and loyalty, we took some preliminary analytical steps. First, we performed four reliability analyses in relation to the food values, satisfaction with the product, loyalty toward the product, and loyalty toward the grocery store. We did not perform this analysis on satisfaction with the grocery store because there was only one variable that could be accommodated in this group. Thus, it was not necessary to carry out this analysis—and by extension, the factorial analysis—-for that variable. The Cronbach's alpha value was acceptable in each of the four cases analyzed, signifying that our measures were reliable. 
Table 5. Descriptive statistics regarding satisfaction and loyalty.

\begin{tabular}{llcc}
\hline & \multicolumn{1}{c}{ Variable } & Mean & Standard Deviation \\
\hline \multirow{5}{*}{ Satisfaction } & Degree of satisfaction with the food you purchased in that last purchase & 4.08 & 0.778 \\
& The food I bought met my expectations & 4.12 & 0.819 \\
& I was satisfied with the purchase experience & 4.18 & 09 \\
& The choice of these foods seemed right to me & 4.08 & 0.817 \\
& The food I bought provided me with an enjoyable experience & 4.13 & 0.854 \\
\hline \multirow{5}{*}{ Loyalty } & Most of the time I shop, I buy the same foods & 4.11 & 0.875 \\
& Most of the time I shop, I come to this grocery store & 4.05 & 0.978 \\
& Most of the time I come to this grocery store, I buy the same foods & 3.45 & 1.907 \\
& Whenever I can, I recommend these foods & 3.51 & 1.139 \\
& Whenever I can, I recommend this grocery store & 4.26 & 0.807 \\
& I intend to keep buying these foods & 4.37 & 0.778 \\
\hline
\end{tabular}

Next, we conducted a factorial analysis, which basically involved a series of procedures for reducing and summarizing the data. This analysis is normally used in market research when a large number of variables are correlated and it is necessary to reduce them to a more manageable level. The analysis resulted in four factors comprising all food value variables, which were labelled as follows:

- Consumer Ethics Value: Containing the food values of naturalness, origin, fairness, environmental impact, and animal welfare. All of these values reflect consumers ethical considerations.

- Basic Consumer Offer: Containing the food values of taste, price, and safety. This group of variables captures the basic aspects of foods that consumers look for when they make a purchase.

- Preferred Value by Young but Well-Prepared: Containing the food values of convenience, nutrition, and tradition. This group name is inspired by the segment of people whose concept emerged in the 1990s when the younger population was leaving the family home to start building a new life. When making a purchase, these people sought products that were easy to prepare, that were healthy as regards their nutrition and that were basic products.

- Preferred by Opinion Leaders: Containing the food values of appearance and novelty. This group comprises those values that are most appreciated by this kind of segment.

The factorial analysis placed the remaining variables into groups featuring one factor each: product satisfaction, grocery store satisfaction, product loyalty and grocery store loyalty. Having obtained the factors, we carried out a correlation analysis in order to verify that the regression would be able to measure the degree of mutual dependence between these variables. After conducting this analysis using Pearson's correlation coefficient, we subsumed the variable "I was satisfied with the purchase experience" into "grocery store satisfaction." The results showed that the factors were indeed correlated and that the regression could be performed.

Main Results: Regression Analysis

Finally, we performed a regression analysis in order to affirm or deny our hypotheses. Table 6 shows that each of the hypotheses was accepted. 
Table 6. Results of regression analysis.

\begin{tabular}{|c|c|c|c|c|c|c|c|c|c|}
\hline $\begin{array}{l}\text { Independent } \\
\text { Variable }\end{array}$ & $\begin{array}{l}\text { Dependent } \\
\text { Variable }\end{array}$ & $\mathbf{R} 2$ & $\begin{array}{l}\text { Standard } \\
\text { Error }\end{array}$ & $\begin{array}{l}\text { Specific Variables within } \\
\text { Independent Variable }\end{array}$ & $\begin{array}{c}\text { Non } \\
\text { Standardized B }\end{array}$ & $p$-Value & Signification & Durbin-Watson & $\begin{array}{l}\text { Hypotheses } \\
\text { Contrast }\end{array}$ \\
\hline \multirow{3}{*}{ Food values } & \multirow{3}{*}{$\begin{array}{l}\text { Product } \\
\text { satisfaction }\end{array}$} & \multirow{3}{*}{0.15} & \multirow{3}{*}{0.928} & Basic consumer offer & 0.281 & 0 & $99 \%$ & \multirow{3}{*}{1.957} & \multirow{3}{*}{ H1a is accepted } \\
\hline & & & & $\begin{array}{l}\text { Preferred value by } \\
\text { opinion leaders }\end{array}$ & 0.207 & 0 & $99 \%$ & & \\
\hline & & & & Consumer ethics value & 0.158 & 0.003 & $99 \%$ & & \\
\hline \multirow{3}{*}{ Food values } & \multirow{3}{*}{$\begin{array}{l}\text { Grocery store } \\
\text { satisfaction }\end{array}$} & \multirow{3}{*}{0.089} & \multirow{3}{*}{0.853} & Basic consumer offer & 0.192 & 0 & $99 \%$ & \multirow{3}{*}{2.01} & \multirow{3}{*}{$\mathrm{H} 1 \mathrm{~b}$ is accepted } \\
\hline & & & & $\begin{array}{l}\text { Preferred value by } \\
\text { opinion leaders }\end{array}$ & 0.132 & 0.008 & $99 \%$ & & \\
\hline & & & & Consumer ethics & 0.118 & 0.017 & $95 \%$ & & \\
\hline \multirow{3}{*}{ Food values } & \multirow{3}{*}{ Product loyalty } & \multirow{3}{*}{0.086} & \multirow{3}{*}{0.963} & Basic consumer offer & 0.191 & 0.001 & $99 \%$ & \multirow{3}{*}{1.94} & \multirow{3}{*}{$\mathrm{H} 2 \mathrm{a}$ is accepted } \\
\hline & & & & $\begin{array}{l}\text { Preferred value by young but } \\
\text { well-prepared }\end{array}$ & 0.159 & 0 & $99 \%$ & & \\
\hline & & & & $\begin{array}{l}\text { Preferred value by } \\
\text { opinion leaders }\end{array}$ & 0.138 & 0.013 & $95 \%$ & & \\
\hline \multirow{2}{*}{ Food values } & \multirow{2}{*}{$\begin{array}{c}\text { Grocery store } \\
\text { loyalty }\end{array}$} & \multirow{2}{*}{0.094} & \multirow{2}{*}{0.958} & $\begin{array}{l}\text { Preferred value by } \\
\text { opinion leaders }\end{array}$ & 0.233 & 0 & $99 \%$ & \multirow{2}{*}{1.868} & \multirow{2}{*}{$\mathrm{H} 2 \mathrm{~b}$ is accepted } \\
\hline & & & & Basic consumer offer & 0.178 & 0.001 & $99 \%$ & & \\
\hline $\begin{array}{l}\text { Grocery store } \\
\text { satisfaction }\end{array}$ & $\begin{array}{l}\text { Grocery store } \\
\text { loyalty }\end{array}$ & 0.177 & 0.909 & Grocery store satisfaction & 0.474 & 0 & $99 \%$ & 1.877 & $\mathrm{H} 3 \mathrm{~b}$ is accepted \\
\hline $\begin{array}{c}\text { Product } \\
\text { satisfaction }\end{array}$ & $\begin{array}{c}\text { Grocery store } \\
\text { loyalty }\end{array}$ & 0.259 & 0.862 & Product satisfaction & 0.509 & 0 & $99 \%$ & 2.015 & $\mathrm{H} 3 \mathrm{c}$ is accepted \\
\hline $\begin{array}{l}\text { Grocery store } \\
\text { satisfaction }\end{array}$ & Product loyalty & 0.147 & 0.925 & Grocery store satisfaction & 0.433 & 0 & $99 \%$ & 1.881 & $\mathrm{H} 3 \mathrm{~d}$ is accepted \\
\hline
\end{tabular}


First, we consider the R2 coefficient, which measures the proportion of variability in the dependent variable that is explained by the independent variable. From this, we can observe how the percentages that explain the greatest proportion of variation of the endogenous variable, in order from highest to lowest, correspond to the following relationships: satisfaction with the product positively and significantly influences loyalty toward the grocery store $(25.9 \%)$; satisfaction with the product has a positive and significant influence on loyalty toward the product $(25.3 \%)$; satisfaction with the grocery store positively and significantly influences loyalty toward the grocery store $(17.7 \%)$; food values have a positive and significant influence on satisfaction with the product $(15.0 \%)$; satisfaction with the grocery store positively and significantly influences consumer loyalty toward the product $(14.7 \%)$; food values positively and significantly influence loyalty toward the grocery store $(9.4 \%)$ as well as satisfaction with the grocery store $(8.9 \%)$; and finally, food values positively and significantly influence consumer loyalty toward the product $(8.6 \%)$. In other words, the highest percentages of explanation are found in those relationships in which satisfaction with the product influences the different types of loyalty. The lowest percentages of explanation are found in those models in which independent variables are factors derived from food values.

Second, we account for the estimated unstandardized B due to which it has been possible to accept all the hypotheses initially proposed. In addition, it has been observed that in those relationships where satisfaction with the product is the independent variable and loyalty the dependent variable (with both the product and the grocery store), it should be highlighted how the strongest impact corresponds to the product satisfaction on both kind of loyalties. While the smallest impact is exerted by grocery store satisfaction on product loyalty (0.433).

Finally, we found that the Basic Consumer Offer factor had the greatest impact on the dependent variable, followed by the factor Preferred By Opinion Leaders. The only instance where this situation was reversed (i.e., the latter factor was more important than the former) was when the loyalty toward the grocery store was used as the dependent variable. Consumer Ethics was the least influential factor in those models, having product satisfaction (0.158) and grocery store satisfaction (0.118) as dependent variables respectively. The factor Preferred By Young But Prepared was only influential on the model where product loyalty was used as the dependent variable (0.159).

For the analysis of autocorrelation, the Durbin-Watson test is used (see Table 6). This statistic limits the results to extreme limits of three broad regions:

- If there is positive autocorrelation, the value of the $\mathrm{d}$ statistic is closed to zero (0).

- If there is negative autocorrelation, the value of the $\mathrm{d}$ statistic is closed to the upper limit that is established at four (4).

- If there is no autocorrelation, the value of the $d$ statistic is at an intermediate value (2).

Since all the $\mathrm{d}$ statistic values are close to 2 , the absence of autocorrelation is verified in all the proposed models.

From the analysis of Table 7, several interesting findings also result. The study of the collinearity between the predetermined variables of the different models applied in our study was carried out based on some of the statistics most widely used for this type of hypothesis, such as the Pearson linear correlation coefficient, the Tolerance (TOL) and Variance Inflation Factor (VIF). In particular, Pearson's linear correlation coefficients show absence of collinearity, all are zero. The same occurs with the other two indicators, the Tolerance (TOL) and Variance Inflation Factors (VIF), both equal to 1, indicating the absence of collinearity between the predetermined variables chosen in the different models. 
Table 7. Results of collinearity analysis.

\begin{tabular}{ccccc}
\hline Pearson Correlation & $\begin{array}{c}\text { Basic } \\
\text { Consumer Offer }\end{array}$ & $\begin{array}{c}\text { Preferred Value by } \\
\text { Opinion Leaders }\end{array}$ & $\begin{array}{c}\text { Preferred Value by Young } \\
\text { but Well-Prepared }\end{array}$ & $\begin{array}{c}\text { Consumer Ethics } \\
\text { Value }\end{array}$ \\
\hline Basic consumer offer & 1.00 & 0.00 & 0.00 & 0.00 \\
\hline $\begin{array}{c}\text { Preferred value by opinion leaders } \\
\begin{array}{c}\text { Preferred value by young but } \\
\text { well-prepared }\end{array}\end{array}$ & 0.00 & 1.00 & 1.00 & 0.00 \\
\hline Consumer ethics value & 0.00 & 0.00 & 0.00 & 1.00 \\
\hline Consumer Offer & $\begin{array}{c}\text { Preferred Value by } \\
\text { Opinion Leaders }\end{array}$ & $\begin{array}{c}\text { Preferred Value by Young } \\
\text { but Well-Prepared }\end{array}$ & $\begin{array}{c}\text { Consumer Ethics } \\
\text { Value }\end{array}$ \\
\hline TOLERANCE (TOL) & 1.00 & 1.00 & 1.00 & 1.00 \\
\hline VARIANCE INFLATION & 1.00 & 1.00 & 1.00 & 1.00 \\
\hline
\end{tabular}

\section{Conclusions and Recommendations}

This work sought to assess the influence of: (i) food values on key non-financial results, particularly satisfaction and loyalty; and (ii) satisfaction on loyalty. We further delineated both the satisfaction and loyalty variables (i.e., with the product and with the grocery store), while also considering the potential implications of the COVID-19 pandemic.

With this objective in mind, we distributed an online questionnaire comprising several questions related to food values, satisfaction (with both the product and the grocery store), loyalty (with product and grocery store), and socio-demographics to a sample of residents from the Toledo province (a city located in central Spain) during April and May 2020. This period was characterized by a national lockdown, where only food grocery stores and essential businesses were open to the public. We obtained 303 valid questionnaires and analyzed the data using descriptive statistics alongside linear parametric regressions.

The results uncovered several interesting findings. First, we confirmed that the most appreciated values are taste, safety, and naturalness, in that order. At first glance, it might seem that the COVID-19 pandemic led consumers to show greater appreciation for securityrelated values. However, this finding is not new and is, in fact, completely coherent with the previous findings (especially with those works that gathered data from the same region a few years ago). Likewise, the least appreciated values-novelty, fairness, and origin, in that order-are also coherent with previous studies. Affirming consumers' consistencyeven amidst the environmental volatility induced by the COVID-19 pandemic-constitutes one interesting contribution of this research.

Second, we observed that the variable "the choice of these foods seemed right to me" received the highest score with regard to product satisfaction, while the variable "I intend to keep coming to this grocery store" scored the highest in terms of loyalty toward the grocery store. In terms of association between the dependent and independent variables (which the R2 measures), the highest explanation corresponded to the influence of satisfaction with the product on the loyalty toward the grocery store; whereas the smallest percentage corresponded to the influence of food values on loyalty toward the product. In other words, to achieve long-term loyalty (both to the product and the store), it seems more important to ensure that consumers are satisfied with the food products they buy, rather than with the store where they buy them. This suggests that retailers need to carefully select the products they buy and take a holistic view of the assortment (length, depth, etc.).). On this point, the small influence of food values on product satisfaction is interesting. This finding could be an indication that although consumers appreciate the values of the food products they purchase when they are in the store, this importance is not as high as that of the relationships measuring the influence of short-term variables (satisfaction variables) on long-term variables (loyalty variables). Which would be also an interesting contribution in this research line. 
Regarding food values, we want to highlight how the Basic Consumer Offer factor had the greatest impact on the dependent variable, followed by the Preferred By Opinion Leaders factor (save for the case where loyalty toward the grocery store was the dependent variable, in which case, the importance reversed). When treating product satisfaction and grocery store satisfaction as the dependent variables, Consumer Ethics was the least influential factor. Meanwhile, the factor Preferred By Young But Prepared was only influential on the model where product loyalty was the dependent variable. Thus, it seems that the values of naturalness, origin, fairness, environmental impact, and animal welfare contained in the factor of consumer offer exert the highest impact on the satisfaction and loyalty variables, while the values of convenience, nutrition and tradition (reflected in the Preferred By Young But Prepared factor) exert the smallest influence on those same variables.

Finally, we want to affirm that product satisfaction had the strongest influence on both product loyalty and grocery store loyalty, while grocery store satisfaction had the smallest effect on product loyalty. Thus, it seems that retailers gain better long-term reactions by ensuring that consumers are satisfied with the values offered by the food products, rather than bolstering their satisfaction with the grocery store itself. In other words, to promote consumers' long-term loyalty to the store, retailers should emphasize aspects that can foster product satisfaction, such as product assortment choice. Likewise, retailers need to be able to correctly communicate the benefits of their products, as consumers' adequate perception of products' values is also very important.

In short, we recommend that grocery retailers dedicate resources to knowing their customers better. Understanding customers' tastes and preferences allows retailers to design better assortments and purchase experiences. By incorporating important food values (and deemphasizing less important ones), retailers can increase customers' satisfaction and thereby galvanize loyalty. Naturally, loyal and satisfied customers will be more likely to make repeat purchases and recommend the store to other consumers.

Of course, our research features some limitations that represent avenues for future studies. First, our sample size of 303 questionnaires was relatively small. Future investigations should see if our results hold with a larger and/or more geographically diverse sample. Second, our participants were heavily skewed toward one type of grocery store (supermarkets) where they made their last purchase. Future studies could properly weight the types of grocery store and complement those efforts with surveys in the grocery stores themselves.

Finally, future research should incorporate variables that encompass other concepts like consumer trust (which can be considered a prelude to loyalty) or social pressure (what real or imagined others think about the purchase).

Author Contributions: Conceptualization, A.I.M.-R., I.R.P.-J., A.E.-D. and M.P.M.-R.; methodology, A.I.M.-R., I.R.P.-J., A.E.-D. and M.P.M.-R.; software, A.I.M.-R., I.R.P.-J., A.E.-D. and M.P.M.-R.; validation, A.I.M.-R., I.R.P.-J., A.E.-D. and M.P.M.-R.; formal analysis, A.I.M.-R., I.R.P.-J., A.E.-D. and M.P.M.-R.; investigation, A.I.M.-R., I.R.P.-J., A.E.-D. and M.P.M.-R.; resources; A.I.M.-R., I.R.P.-J., A.E.-D. and M.P.M.-R.; data curation, A.I.M.-R., I.R.P.-J., A.E.-D. and M.P.M.-R.; writing-original draft preparation, A.I.M.-R., I.R.P.-J., A.E.-D. and M.P.M.-R.; writing-review and editing A.I.M.-R., I.R.P.-J., A.E.-D. and M.P.M.-R.; visualization, A.I.M.-R., I.R.P.-J., A.E.-D. and M.P.M.-R.; supervision, A.I.M.-R., I.R.P.-J., A.E.-D. and M.P.M.-R.; project administration, A.I.M.-R., I.R.P.-J., A.E.-D. and M.P.M.-R.; funding acquisition A.I.M.-R., I.R.P.-J., A.E.-D. and M.P.M.-R. All authors contributed equally to this research. All authors have read and agreed to the published version of the manuscript.

Funding: This Research has been funded by European Regional Development Fund (FEDER_Plan Propio de Investigación), Group “Observatorio de la Innovación en Distribución Comercial”.

Institutional Review Board Statement: Not applicable.

Informed Consent Statement: Not applicable. 
Data Availability Statement: The data presented in this study are available upon request from the corresponding author. The data are not publicly available due to participants were guaranteed, as a requirement to respond, that their data would be kept anonymous and that no personal data would be collected.

Acknowledgments: Group “Observatorio de la Innovación en Distribución Comercial."

Conflicts of Interest: The authors declare no conflict of interest.

\section{References}

1. Alves, F.; Mendes, C.; Aparecida, M. Atributos determinantes nadecisão de compra de consumidores de alimentos orgânicos. Agroalimentaria 2012, 18, 75-86.

2. Martínez-Ruiz, M.P.; Gómez-Cantó, C.M. Key external influences affecting consumers' decisions regarding food. Front. Psychol. 2016, 7, 1618. [CrossRef]

3. Lusk, J.L.; Briggeman, B.C. Food values. Am. J. Agric. Econ. 2009, 91, 184-196. [CrossRef]

4. Gómez-Cantó, C.M.; Martínez-Ruiz, M.P.; Izquierdo-Yusta, A. Food Values and the Spanish Consumer: Evidences Obtained in Different Segments. Nutr. Food Sci. 2018, 5, 555651.

5. Martínez Ruiz, M.P.; Ruiz-Palomino, P.; Martinez-Canas, R.; Blázquez-Resino, J.J. Consumer satisfaction and loyalty in privatelabel food stores. Br. Food J. 2014, 116, 849-871. [CrossRef]

6. Izquierdo-Yusta, A.; Gómez-Cantó, C.M.; Pelegrin-Borondo, J.; Martínez-Ruiz, M.P. Consumers' behaviour in fast-food restaurants: A food value perspective from Spain. Br. Food J. 2019, 121, 386-399. [CrossRef]

7. Izquierdo-Yusta, A.; Gómez-Cantó, C.M.; Martínez-Ruiz, M.P.; Pérez-Villarreal, H.H. The influence of food values on postpurchase variables at food establishments. Br. Food J. 2020, 122, 2061-2076. [CrossRef]

8. $\quad$ Rokeach, M. The Nature of Human Values; Free Press: New York, NY, USA, 1973.

9. Schwartz, S.H. Universals in the Content and Structure of Values: Theoretical Advances and Empirical Tests in 20 Countries. Adv. Exp. Soc. Psychol. 1992, 25, 1-65.

10. Steptoe, A.; Pollard, T.M.; Wardle, J. Development of a Measure of the Motives Underlying the Selection of Food: The Food Choice Questionnaire. Appetite 1995, 25, 267-284. [CrossRef]

11. Bazzani, C.; Gustavsen, G.W.; Nayga, R.M., Jr.; Rickertsen, K. A comparative study of food values between the United States and Norway. Eur. Rev. Agric. Econ. 2018, 45, 239-272. [CrossRef]

12. Novelli, D. Alimentos: El consumo responsable trastoca paradigmas. RIA 2018, 4, 4-9.

13. Olsen, S.O.; Wilcox, J.; Olsson, U. Consequences of ambivalence on satisfaction and loyalty. Psychol. Mark. 2005, 22, 247-269. [CrossRef]

14. Bloemer, J.; De Ruyter, K. On the relationship between store image, store satisfaction and store loyalty. Eur. J. Mark. 1998, 32, 499-513. [CrossRef]

15. Sudari, S.; Tarofder, A.; Khatibi, A.; Tham, J. Measuring the critical effect of marketing mix on customer loyalty through customer satisfaction in food and beverage products. Manag. Sci. Lett. 2019, 9, 1385-1396. [CrossRef]

16. Giese, J.L.; Cote, J.A. Defining consumer satisfaction. Acad. Mark. Sci. Rev. 2000, 1, 1-24.

17. Stefani, G.; Romano, D.; Cvicchi, A. Consumer expectations, liking and willingness to pay for specialty foods: Do sensory characteristics tell the whole story? Food Qual. Prefer. 2006, 17, 53-62. [CrossRef]

18. Vad Andersen, B.; Hyldig, G. Consumer's view on determinants to food satisfaction, A qualitative approach. Appetite 2015, 95, 9-16. [CrossRef]

19. Huddleston, P.; Whipple, J.; VanAuken, A. Food store loyalty: Application of a consumer loyalty framework. J. Target. Meas. Anal. Mark. 2003, 12, 213-230. [CrossRef]

20. Carpenter, J.M.; Fairhurst, A. Consumer shopping value, satisfaction, and loyalty for retail apparel brands. J. Fash. Mark. Manag. Int. J. 2005, 9, 256-269. [CrossRef]

21. Carpenter, J.M.; Moore, M. Consumer demographics store attributes and retail format choice in the US grocery market. Int. J. Retail Distrib. Manag. 2006, 34, 434-452. [CrossRef]

22. East, R.; Harris, P.; Willson, G.; Lomax, W. Loyalty to supermarkets, The International Review of Retail. Distrib. Consum. Res. 1995, 5, 99-109. [CrossRef]

23. Anderson, E.; Weitz, B. The Use of Pledges to Build and Sustain Commitment in Distribution Channels. J. Mark. Res. 1992, 29, 21-26. [CrossRef]

24. Moorman, C.; Zaltman, G.; Deshpande, R. Relationships between providers and users of marketing research: The dynamics of trust within and between organizations. J. Mark. Res. 1992, 29, 314-329. [CrossRef]

25. Morgan, R.M.; Hunt, S.D. The commitment-trust Theory of relationship marketing. J. Mark. 1994, 58, 20-38. [CrossRef]

26. Oliver, R.L. Whence consumer loyalty. J. Mark. 1999, 63, 33-44. [CrossRef]

27. Liu, A.H. Customer value and switching costs in business services: Developing exit barriers through strategic value management. J. Bus. Ind. Mark. 2006, 21, 30-37. [CrossRef]

28. Meesala, A.; Paul, J. Service quality, consumer satisfaction and loyalty in hospitals: Thinking for the future. J. Consum. 2018, 40, 261-269. [CrossRef] 
29. Hu, H.Y.; Cheng, C.C.; Chiu, S.I.; Hong, F.Y. A study of customer satisfaction, customer loyalty and quality attributes in Taiwan's medical service industry. Afr. J. Bus. Manag. 2011, 5, 187.

30. Dudek-Burlikowska, M.; Szewieczek, D. Customer's satisfaction the element of proquality strategies of organization. J. Achiev. Mater. Manuf. Eng. 2008, 28, 91-94.

31. Deng, Z.; Lu, Y.; Wei, K.K.; Zhang, J. Understanding Customer Satisfaction and Loyalty: An Empirical Study of Mobile Instant Messages in China. Int. J. Inf. Manag. 2010, 30, 289-300. [CrossRef]

32. Fornell, C.; Johnson, M.D.; Anderson, E.W.; Cha, J.; Bryant, B.E. The American Customer Satisfaction Index: Nature, purpose, and findings. J. Mark. 1996, 60, 7-18. [CrossRef]

33. Gustafsson, A.; Johnson, M.D.; Roos, I. The Effects of Customer Satisfaction, Relationship Commitment Dimensions, and Triggers on Customer Retention. J. Mark. 2005, 69, 210-218. [CrossRef]

34. Mittal, V.; Kamakura, W.A. A Kamakura Satisfaction, Repurchase Intent, and Repurchase Behavior: Investigating the Moderating Effect of Customer Characteristics. J. Mark. Res. 2001, 38, 131-142. [CrossRef]

35. Mittal, B.; Lassar, W.M. Why do customers switch? The dynamics of satisfaction versus loyalty. J. Serv. Mark. 1998, 12, 177-194. [CrossRef]

36. Kamran-Disfani, O.; Mantrala, M.K.; Izquierdo-Yusta, A.; Martínez-Ruiz, M.P. The impact of retail store format on the satisfactionloyalty link: An empirical investigation. J. Bus. Res. 2017, 77, 14-22. [CrossRef]

37. Instituto Nacional de Estadística. Población Residente Por Fecha, Sexo y Edad. Recuperado de. Available online: www.ine.es/jaxiT3 /Datos.htm?t=31304 (accessed on 20 March 2021). 